\title{
DESIGN OF AN ENERGY EFFICIENT AUTOTRANSFORMER FOR STARTING AN INDUCTION MOTOR
}

\author{
Madhu PALATI*, Ramaswamy TIRUNELLAI VENKATADHRI**, Akshata KAMAGOUDA*, \\ Prashant ILKAL ${ }^{*}$, Shilpa LAGAMANNANAGARALE* ${ }^{*}$ Umadevi HANUMANTHARAYAPPA* \\ *Department of Electrical \& Electronics Engineering, School of Engineering \& Technology, \\ Jain University, Jakkasandra Post, Kanakapura Taluk, Ramanagara District, Karnataka - 562112, India, \\ Tel.: +91-9686596133, E-mail: mfmadhu@gmail.com \\ ${ }^{* *}$ Transformer Designer, Sara Consultants, Hanumanth nagar, Bangalore - 560019, India
}

\begin{abstract}
Induction motors are widely used in most of the Industries. Induction motors draw very high current in the order of 5 to 8 times the rated current during starting. Starting of a higher rating Induction motor using Autotransformer has been found great importance in limiting the starting current and improving the starting torque compared to star-delta starter. This paper discusses the design and analysis of an energy efficient Autotransformer starter of rating $6.6 \mathrm{kV}, 110 \mathrm{kVA}$ to start an induction motor of rating 6.6 $\mathrm{kV}, 250 \mathrm{KW}$. The Autotransformer was designed with on-load tap changing facility of eight tapping's ranging from $50 \%$ to $85 \%$ with each step tapping of 5\%. Laser Scribed 23ZDMH85 material and conductor of current density $3.07 \mathrm{~A} / \mathrm{mm}^{2}$ are proposed in the present work to reduce the total losses. The feasibility of achieving a reduction of about $22 \%$ in total losses compared to conventional transformer is discussed in detail. At 50\% tapping, unity power factor the estimated efficiency of the autotransformer is $99.21 \%$.
\end{abstract}

Keywords: induction motor, autotransformer, starting current, on-load tap-changer, Laser Scribed 23ZDMH85, losses

\section{INTRODUCTION}

The increasing demand for electricity in India, all electric utility companies are going for energy efficient electrical equipment. Ninety percent of the motors used in industries are induction motors. When a 3- phase induction motor of higher rating is switched on directly from the mains, it draws a starting current of about $5-8$ times the full load (depending upon on the design) current. Also, this will cause a drop in the voltage affecting the performance of other loads connected to the mains. Therefore, starters are used to limit the starting current drawn by the 3-phase induction motors [1].

Common methods employed for starting an induction motor are Direct- on-line starter (DOL), Star-Delta starter, Autotransformer Starter and Soft starters. DOL starters are used to start induction motors of rating less than $5 \mathrm{HP}$ and for starting medium rating induction motors, Star-Delta starters are used. For starting higher rating induction motors, Autotransformer starters are used and for very high rating induction motors, Soft starters are used.

The work carried out by the earlier researchers in the area of autotransformer starter design and development is briefly presented in this section.

Daniel J Rogers investigated characteristics of contact operated under new hybrid diverter design for on-load tap changer [2].

Wenzhou et al. investigated the effects of laser scribing on surface coating and magnetic properties of silicon steel [3].

Ajay et al. presented an overview of the transformer design, optimization and evaluation of energy efficient transformers from the literature related to this field for the past forty years [4].

Harsha et al. discussed and analysed different motor starters (conventional electromechanical and electronic starters), disadvantages and energy saving features of each type of starter [5].
Larry B Farr has discussed high voltage stress failures of auto transformer starter ratings ranging from $2400 \mathrm{~V}$ to $11 \mathrm{kV}$ and the cause for failure [6].

Sewan et al. proposed several auto transformer arrangements to enhance the power quality of high current DC power supply [7].

In the present work, design and analysis of Autotransformer starter of rating $6.6 \mathrm{kV}, 110 \mathrm{kVA}$ to start an induction motor of rating $6.6 \mathrm{kV}, 250 \mathrm{KW}$ is discussed in detail.

\subsection{Significance of Autotransformer}

In Star-Delta starter the starting current is limited by a factor of (1/3). This limitation is overcome in Autotransformer starter. The starting current is given by $\mathrm{K}^{2} * \mathrm{I}_{\mathrm{sc}}$, where $\mathrm{K}$ is the transformation ratio and $\mathrm{I}_{\mathrm{sc}}$ is the short circuit current.

An auto transformer starter is suitable for both star and delta connected motors. The starting current and torque can be adjusted to any desired value by selecting the suitable tapping position in an auto transformer. The schematic diagram of auto transformer is shown in Fig. 1 [1].

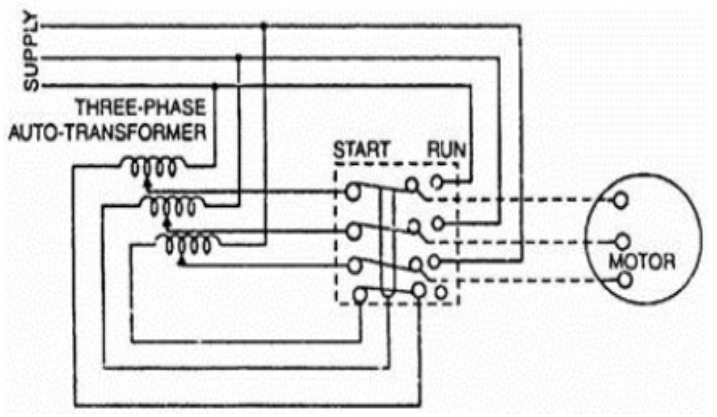

Fig. 1 Schematic diagram of auto transformer starter for starting an induction motor 
Initially the starter is connected to start position where reduced voltage gets applied to the stator of the induction motor, once the motor reaches $80 \%$ of its rated speed the starter switch is positioned to RUN and full voltage gets applied to the stator.

\subsection{On-Load tap changer for an Autotransformer}

Interruption of huge starting current results in arcing and damages the contacts. By using on-load tap changing mechanism, arcing at the contacts is avoided and the life of the contacts is increased. Fig. 2 to Fig. 4 shows the tap changing mechanism from 50\% tapping to 55\% taping position. $S_{1} \& S_{2}$ represent selector switches, $T_{1} \& T_{2}$ represents toggle switches and $\mathrm{I}_{\mathrm{L}}$ represents the load current. During starting, tap changer is set to $50 \%$ tapping to provide required starting torque. As shown in Fig. 2, $\mathrm{S}_{1} \& \mathrm{~S}_{2}, \mathrm{~T}_{1} \& \mathrm{~T}_{2}$ are in closed position, current flowing through the selector switch is half the total load current $\left(\mathrm{I}_{\mathrm{L}} / 2\right)$.

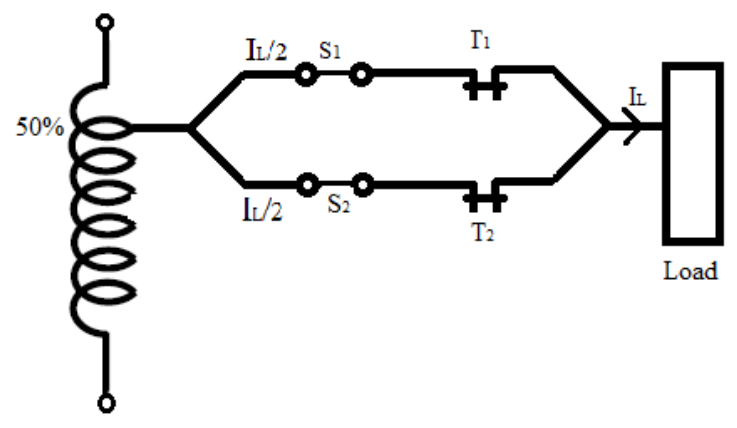

Fig. 2 On-Load tap changer at 50\% tapping

The tapping has to be changed from $50 \%$ to $55 \%$. First toggle switch $\mathrm{T}_{2}$ is opened, the total load current gets diverted and flows through $\mathrm{S}_{1}$ to the load. Now $\mathrm{S}_{2}$ is moved to $55 \%$ as shown in Fig. 3(a). Now $T_{2}$ is closed as shown in Fig. 3(b) and there will be circulating current. In practice this current is limited by connecting reactors in the circuit and losses due to this current are minimized. In the next step $T_{1}$ is opened and the total load current flows through $\mathrm{S}_{2}$. Selector switch $\mathrm{S}_{1}$ is moved to $55 \%$ tapping as shown in Fig. 4 and $T_{1}$ is closed. The total load current gets divided equally and flows through the switches $\mathrm{S}_{1}$ and $\mathrm{S}_{2}$.

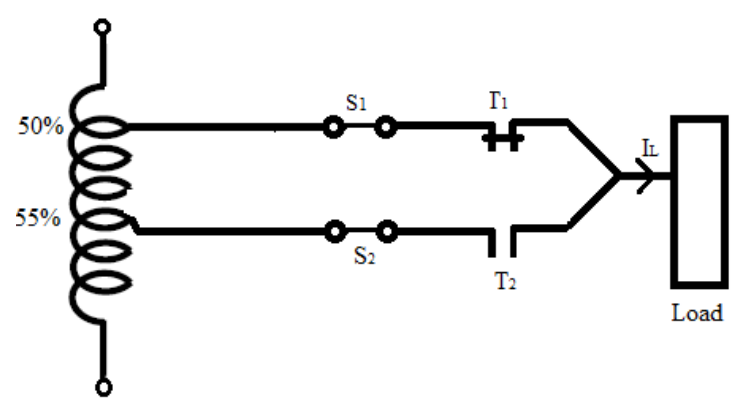

Fig. 3(a) On-Load tap changer with $\mathrm{S}_{1}$ at $50 \%$ and $\mathrm{S}_{2}$ at $55 \%$ tapping and $\mathrm{T}_{2}$ open

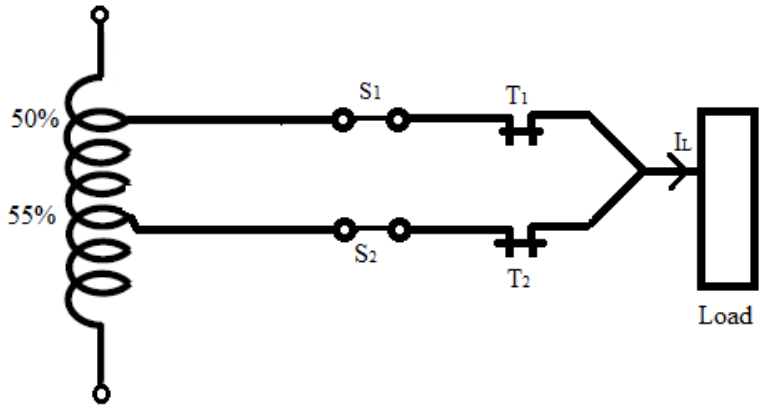

Fig. 3(b) On-Load tap changer with $\mathrm{S}_{1}$ at $50 \%$ and $\mathrm{S}_{2}$ at $55 \%$ tapping and $\mathrm{T}_{2}$ closed

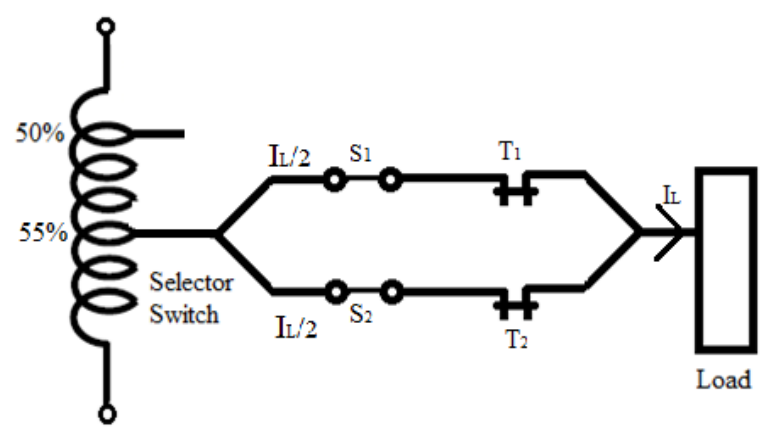

Fig. 4 On-Load tap changer at 55\% tapping

\section{DESIGN OF AUTOTRANSFORMER}

The flow chart for designing autotransformer is shown in Fig. 5. The design of $6.6 \mathrm{kV}, 110 \mathrm{kVA}$ auto transformer is carried out in accordance with Indian Standards. The materials used for designing the autotransformer are ferromagnetic core, conductors, insulating materials, sealing materials etc. For energy efficient application, to minimize the core loss, laser scribed $0.23 \mathrm{~mm}$ thickness 23ZDMH85 CRGO silicon steel which has specific loss of 0.56 watts $/ \mathrm{kg}$ and conductor of current density 3.07 $\mathrm{A} / \mathrm{mm} 2$ is considered. The tapings are provided from $50 \%$ to $85 \%$ with a step voltage of $5 \%$.

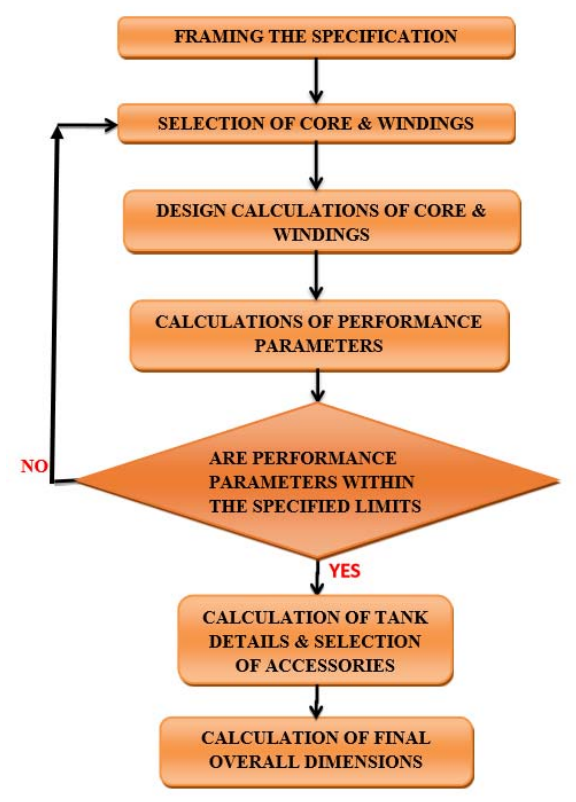

Fig. 5 Flowchart for design of Autotransformer 


\subsection{Design of stepped core}

In a Non-step Lap joint the flux which crosses the air gap contributes to "leakage of flux" and therefore requires more no- load current to achieve the required flux density. Further the over-saturation of flux at the corner joints [8] also leads to higher magnetostriction of the core, which is the main cause of noise level in a transformer.

In stepped Lap core, there will be more layers of laminations available for distributing the flux resulting in lower losses at the corner joints. Therefore, in conventional transformers, non-step lap core is used and in energy efficient transformers step lap core is used. In the present work, to minimize the core losses, Laser scribed $0.3 \mathrm{~mm}$ thickness 23ZDMH85 CRGO silicon steel which has a specific loss of 0.56 watts $/ \mathrm{kg}$ was used.

\subsubsection{Parameters of a stepped core}

Volts per turn is given by

$\frac{\mathrm{v}}{\mathrm{T}}=\mathrm{k} \sqrt{\mathrm{kVA}}$

For designing a $6.6 \mathrm{kV}, 110 \mathrm{kVA}$ energy efficient transformer, $\mathrm{k}$ value was chosen as 0.5 . Therefore, from equation (1), volts per turn are 5.23.

Voltage per phase $=\frac{6.6 \mathrm{kV}}{\sqrt{3}}=3810 \mathrm{~V}$

Number of turns per phase $=\frac{3810 \mathrm{~V}}{5.23 \mathrm{~V} / \mathrm{turn}}=728$

Actual turns per phase are 720 . Therefore, volts per turn is 5.29. The EMF equation of a transformer is given by equation (2)

$E=4.44 * \mathrm{f} * B_{m} * A_{i} * \mathrm{~T} * 10^{-6}$

$\mathrm{E}=\mathrm{V}$, equation (2) is simplified as

$\frac{V}{T}=4.44 * \mathrm{f} * B_{m} * A_{i} * 10^{-6}$

Substituting the values of $(\mathrm{V} / \mathrm{T})$, frequency $=50 \mathrm{~Hz}$ and $\mathrm{B}=1.5 \mathrm{~T}$ in equation (3), Net area, $\mathrm{A}_{\mathrm{i}}$ is obtained and is equal to $15893 \mathrm{~mm}^{2}$. Gross area is given by

$\frac{\pi D^{2}}{4}=\frac{\text { Net area }}{\text { packing factor }} \frac{15893}{0.91}=17465 \mathrm{~mm}^{2}$

Table 1 Stepped core parameters

\begin{tabular}{|c|c|c|c|c|c|}
\hline Steps & $\begin{array}{c}\text { Width } \\
\text { mm }\end{array}$ & $\begin{array}{c}\text { Stack } \\
\text { height } \\
\text { mm }\end{array}$ & $\begin{array}{c}\text { Gross } \\
\text { Area } \\
\text { mm }^{2}\end{array}$ & $\begin{array}{l}\text { Net } \\
\text { area } \\
\text { mm }^{2}\end{array}$ & $\begin{array}{c}\text { ¿Area } \\
\text { mm }^{2}\end{array}$ \\
\hline 1 & 145 & 38 & 5510 & 5344 & 5344 \\
\hline 2 & 135 & 26 & 3510 & 3404 & 8748 \\
\hline 3 & 125 & 18 & 2250 & 2182 & 10930 \\
\hline 4 & 115 & 14 & 1610 & 1561 & 12491 \\
\hline 5 & 105 & 10 & 1050 & 1018 & 13509 \\
\hline 6 & 95 & 10 & 950 & 921 & 14430 \\
\hline 7 & 65 & 18 & 1170 & 1134 & 15564 \\
\hline 8 & 35 & 11 & 385 & 373 & 15937 \\
\hline
\end{tabular}

From above, $\mathrm{D}=150 \mathrm{~mm}$ and 8 steps are considered in the present case. Between any two consecutive steps from step 1 to step 6 , difference of $10 \mathrm{~mm}$ is maintained and to balance in last two steps $30 \mathrm{~mm}$ difference is maintained.

Gross area $=$ stack width $*$ stack height

Net area $=$ Gross area $*$ packing factor

Here, packing factor is taken as 0.97 . The stepped core parameters are shown in Table 1.

\subsection{Design of common winding}

An autotransformer has a single winding, the primary and secondary circuits therefore have a number of winding turns in common. The schematic of autotransformer is shown in Fig. 6.

The maximum current in the common winding is given by $\frac{110 * \mathrm{KVA}}{\sqrt{3} * 6.6 * \mathrm{KV}} \cong 9.63 \mathrm{~A}$. The cross section of conductor is given by

$\frac{\text { maximum current }}{\text { maximum current density }}=\frac{9.63}{3.26}=2.95 \mathrm{~mm}^{2}$

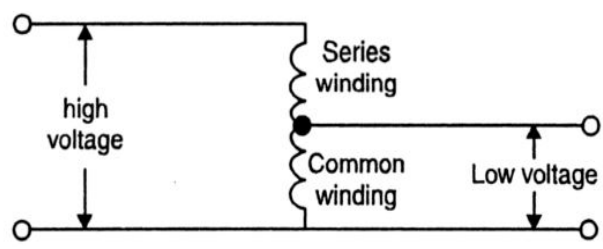

Fig. 6 Schematic diagram of an autotransformer

From equation (4), the diameter of the bare conductor, $\mathrm{b}$ is $2 \mathrm{~mm}$. The total insulation between two bare conductors is $0.25 \mathrm{~mm}$. Therefore, insulated conductor diameter, $b_{\mathrm{i}}$ is $2.25 \mathrm{~mm}$. For $6.6 \mathrm{kV}$ application, as per IS standard 2026, yoke to common winding clearance is 30 $\mathrm{mm}$.

Common winding length is given by

window height $-(2 *$ end clearance $)$

$=375-(2 * 30)=315 \mathrm{~mm}$

Axial forces are more than radial forces, hence we consider turns axially.

Turns per layer $=\frac{\text { winding length }}{\text { insulated conductor diameter }}-1$

Turns per layer $=\frac{315}{2.25}-1=139$

Common winding turns $=360$

Number of layers $=\frac{\text { winding turns }}{\text { Turns per layer }}=\frac{360}{139}=2.58$

The window height for an autotransformer starter can be 2 to 4 times the diameter of the core. In the present work, the window height is considered as 2.5 times the diameter of the core and is equal to $375 \mathrm{~mm}$. For $6600 \mathrm{~V}$ application, as per IS 2026, the clearance required between core and inner winding is $9 \mathrm{~mm}$. Inner diameter, ID of common winding is given by

$=\mathrm{D}+(2 *$ clearance $)=150+(2 * 9)=168 \mathrm{~mm}$ $\left(\mathrm{b}_{\mathrm{i}}{ }^{*}\right.$ oil duct between two layers $)+$ 
(no of ducts*oil duct between two layers)

$=(2.25 * 3)+(2 * 3)=13 \mathrm{~mm}$

Outer diameter, OD of common winding is given by

Inner diameter + radial height

$=168+(2 * 13)=194 \mathrm{~mm}$

Length of mean turn, lmt $=\left(\frac{\mathrm{ID}+\mathrm{OD}}{2}\right) * \pi$

Using equation (10), $1 \mathrm{mt}=568 \mathrm{~mm}=0.568 \mathrm{~m}$.

Length of conductor is given by

$1 \mathrm{mt} *$ no of turns $*$ no of limbs

$=0.568 \mathrm{~m} * 360 * 3=615 \mathrm{~m}$

Volume of conductor is given by

area of conductor * length of conductor

Bare weight, w of common winding conductor is given by

Volume of conductor * density of copper

$\frac{\pi}{4} * 200^{2} * 10^{-4} \mathrm{~cm}^{2} * 615 * 10^{2} \mathrm{~cm} * 8.89 * 10^{-3} \frac{\mathrm{kg}}{\mathrm{cc}}$

$=17.2 \mathrm{~kg}$

Insulated weight, $\mathrm{w}_{\mathrm{i}}$ is given by

$\left\{\left(\frac{\mathrm{b}_{\mathrm{i}}{ }^{2}-\mathrm{b}^{2}}{\mathrm{~b}} * \frac{\text { Density of insulation }}{\text { Density of conductor }}\right)+1\right\} *$ bare weight

$=\left\{\left(\frac{2.25^{2}-2^{2}}{2^{2}} * \frac{1 * 10^{-3}}{8.89 * 10^{-3}}\right)+1\right\} * 17.2 \approx 17.8 \mathrm{kgs}$

Stray loss, $\mathrm{W}_{\mathrm{s}}$ is given by

$\left(\sqrt{\frac{\mathrm{b} *(\mathrm{~T} / \mathrm{l})}{\mathrm{bi} *(T / l)-\text { insulation }}} * \text { Stray loss factor } * \frac{\mathrm{h}}{10}\right)^{4} *$

$\left(\frac{(\text { no.of radial parallel } * \text { no.of layers })^{2}-0.2}{9}\right) * 100$

$\left(\sqrt{\frac{2 * 139}{(2.25 * 139)-0.25}} * 0.8 * \frac{2}{10}\right)^{4} * \frac{(3 * 1)^{2}-0.2}{9} * 100$

$=0.051$

Current density, $\mathrm{J}$ is $3.07 \mathrm{~A} / \mathrm{mm}^{2}$ and load loss is always defined at $75^{\circ} \mathrm{C}(20+55)$, since average ambient temperature is $20^{\circ} \mathrm{C}$ and as per IS2026 winding temperature in India is considered as $55^{\circ} \mathrm{C}$. Load loss, $\mathrm{W}_{\mathrm{L}}$ is given by

Load loss factor $*$ bare weight $*$ (current density) $)^{2} *$ stray losses

As per Indian standards, Load loss factor is 2.4 and load loss at $75^{\circ} \mathrm{C}$ is

$2.4 * 17.2 *(3.07)^{2}\left(\frac{0.051}{100}+1\right) \cong 390 \mathrm{~W}$

The temperature gradient is given by

$$
\text { LoadLoss }
$$

(No of limbs $*$ no of surfaces $*$ heat dissipation factor $*$ winding length $*$ length of mean turn)

$=\frac{390}{(3 * 4.5 * 60 * 0.315 * 0.568)} \cong 2.7^{\circ} \mathrm{C}$

As per IS2026, hot spot temperature is $98^{\circ} \mathrm{C}$ and yearly weighted average ambient temperature in India is $32^{\circ} \mathrm{C}$. Therefore, the maximum winding temperature is $66^{\circ} \mathrm{C}$ (98-32). Maximum permissible temperature gradient is $\frac{66-50}{1.1} \cong 14.5^{\circ} \mathrm{C}$.

\subsection{Design of series winding}

When an autotransformer operates at $50 \%$ of the rated voltage, the maximum current that flows in the series winding of 360 turns is $9.63 \mathrm{~A}$. In the present work, conductor of diameter $2 \mathrm{~mm}$ with current density $3.07 \mathrm{~A} / \mathrm{mm}^{2}$ was considered. The series winding parameters were estimated using the equations given in section 2.2.

Inner diameter of series winding $=206 \mathrm{~mm}$

Outer diameter of series winding $=232 \mathrm{~mm}$

Length of mean turn $=0.688 \mathrm{~m}$

Length of conductor $=744 \mathrm{~m}$

Bare weight of conductor $=20.8 \mathrm{~kg}$

Insulated weight of conductor $=21.5 \mathrm{~kg}$

Stray loss $=0.051 \%$

Load loss $=475 \mathrm{~W}$

Temperature gradient $=2.6^{\circ} \mathrm{C}$

As per IS2026, tank loss is given as $1 \mathrm{~W} / \mathrm{kVA}$. For 110 kVA transformer, total tank losses are $110 \mathrm{~W}$.

Total load loss is given by

Load losses in common winding + Load losses in series winding + Tank losses

$=475+390+110=975 \mathrm{~W}$

\subsection{Estimation of core dimensions}

\subsubsection{Estimation of Length and center distance of core [11]}

The schematic of core is shown in Fig. 7.

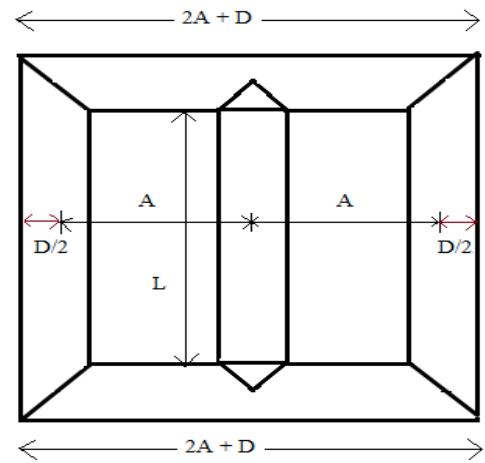

Fig. 7 Schematic of core

Diameter of core $=150 \mathrm{~mm}$

Window height, $\mathrm{L}=375 \mathrm{~mm}$

Centre to center distance, $\mathrm{A}$ is given by

Outer diameter of series winding + clearance

$=232+13=245 \mathrm{~mm}$

Length of the core $=4 \mathrm{~A}+2 \mathrm{D}+3 \mathrm{~L}$

$=(2 * 150+3 * 375+4 * 245)=2405 \mathrm{~mm}$

Weight of core is given by

Length * area*density of CRGO steel [9]

$=2405 * 15937 * 7.65 * 10^{-6} \mathrm{~kg} \approx 294 \mathrm{~kg}$

Core loss is given by

Weight of core * specific loss * build factor

$=294 * 0.56 * 1.15=190 \mathrm{~W}$

\subsubsection{Design of core blades}

\subsubsection{Side limb}

Length of side limb $=\mathrm{L}+\mathrm{D}=520 \mathrm{~mm}$

Width $=145 \mathrm{~mm}$, stacking factor $=0.97$, density of CRGO steel $=7.65 \mathrm{~g} / \mathrm{cc}$ and Core $\mathrm{stack}=38 \mathrm{~mm}$ 
Weight of side limb is given by

Length*width*stacking factor*core stack* density of CRGO steel

$=520 * 145^{*} 0.97 * 38 * 7.65 * 10^{-6}=21.26 \mathrm{~kg}$

\subsubsection{Centre $\operatorname{limb}$}

The schematic of centre limb is shown in Fig. 8.

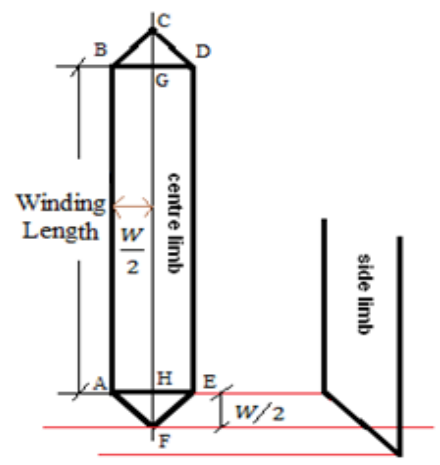

Fig. 8 Schematic of Centre limb

From Fig. 8, total area of the center limb is given by Rectangle ABDE + Area of four triangles (BCG, DCG, $\mathrm{AFH} \& \mathrm{EFH})$

$=(375 * 145)+(4 * 145 * 145 / 4)=75400 \mathrm{~mm}^{2}$

Stacking factor $=0.97$, density of $\mathrm{CRGO}$ steel $=7.65 \mathrm{~g} / \mathrm{cc}$ and core stack $=38 \mathrm{~mm}$

From equation (23), weight of center limb

$=75400 * 0.97 * 38 * 7.65 * 10^{-6}=21.26 \mathrm{~kg}$

\subsubsection{Top yoke}

The schematic of top yoke is shown in Fig. 9.

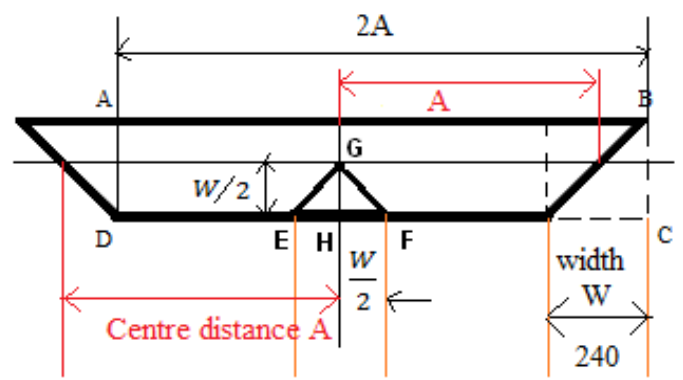

Fig. 9 Schematic of Top yoke

Total area of top yoke is given by

Area of rectangle $\mathrm{ABCD}$ - area of triangles (EGH \&FGH) i.e. $2 \mathrm{AW}-\left(\mathrm{W}^{2} / 4\right)=65794 \mathrm{~mm}^{2}$

For stack $=38 \mathrm{~mm}$, stacking factor $=0.97$ and density $=$ $7.65 \mathrm{~g} / \mathrm{cc}$, the weight of top yoke is calculated using equation (22) and is equal to $18.55 \mathrm{~kg}$. The weight of bottom yoke $=$ weight of top yoke $=18.55 \mathrm{~kg}$.

\subsection{Design of tank}

The top view of transformer tank with three phase windings is shown in Fig. 10.

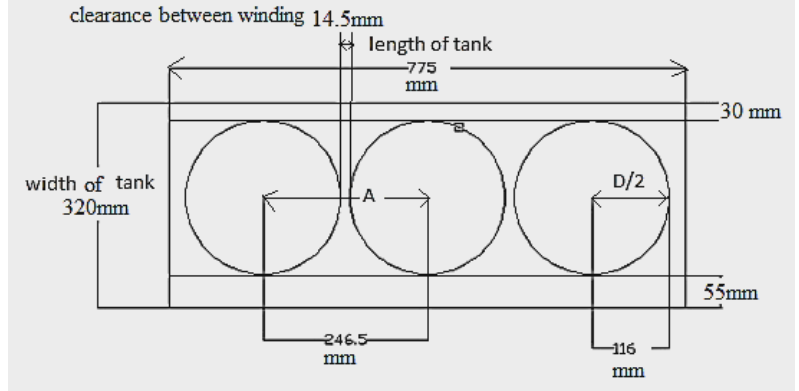

Fig. 10 Top view of transformer tank

From Fig. 10, the center distance is given by Outer diameter of series winding + phase to phase clearance $=232+14.5=246.5 \mathrm{~mm}$

Length of the tank, $\mathrm{L}$ is given by

(2* tank to winding clearance) + OD of series winding + (2* centre distance)

$=(2 * 25)+232+(2 * 246.5)=775 \mathrm{~mm}=0.775 \mathrm{~m}$

Width of the tank, $\mathrm{B}$ is given by

winding to tank clearance at the top and bottom + OD of series winding

$=30$ (top clearance) +55 (bottom clearance) $+232=320$ $\mathrm{mm}=0.32 \mathrm{~m}$

Height of tank, $\mathrm{H}$ shown in Fig. 11 is given by winding length + diameter of top and bottom yoke +clearance at bottom of the tank + clearance at top of the tank (tap changer clearance)

$=380+(2 * 145)+10+100=780 \mathrm{~mm}=0.78 \mathrm{~m}$

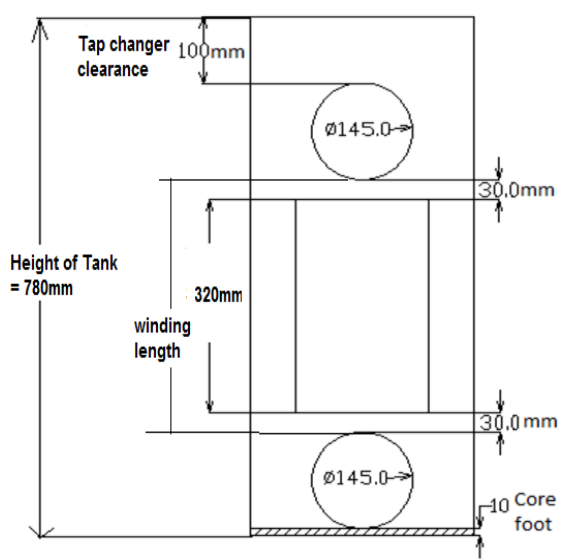

Fig. 11 Schematic of side view of tank

Volume of tank

$=\mathrm{L} * \mathrm{~B} * \mathrm{H}=0.775 * 0.32 * 0.78=0.193 \mathrm{~m}^{3}=193$ litres.

Oil displacement due to core is given by

$\frac{\text { Weight of core }}{\text { Density }}=\frac{294}{7.65}=38$ litres

Oil displacement due to winding is given by

Weight of winding(series \& common $)+$ connections

$=\frac{17.2+20.8+3}{8.89} \cong 5$ litres

Density

Oil displacement due to insulation is 5 litres.

Oil displacement due to mild steel parts is 4 litres.

Total oil displacement due to active parts is given by $38+5+5+4=52$ litres. 
Volume of oil in tank is given by tank capacity- total oil displacement due to active parts $=193-52=141$ litres. No load loss $=190 \mathrm{~W}$, total load loss $=975 \mathrm{~W}$.

Heat dissipated is given by

$$
\begin{aligned}
& \left(\frac{55}{50}\right)^{1 / 0.7} *(\text { No load loss }+1.1 * \text { Load loss }) \\
& =1.146 *(190+(1.1 * 975))=1450 \mathrm{~W}
\end{aligned}
$$

The bottom plate does not contribute to any heat dissipation and on top surface the LV and HV bushings are present, do not allow any heat dissipation by tank wall surface. Therefore, only four sides of the tank were considered. As per standards [10] $500 \mathrm{~W} / \mathrm{m}^{2}$ is dissipated.

Surface Area is given by $2(1+b) * \mathrm{~h}$

$=2(0.775+0.32) * 0.78=1.708 \mathrm{~m}^{2}$

Heat dissipated by tank $=1.708 * 500=850 \mathrm{~W}$

Heat dissipated in Radiators is given by Heat to be dissipated - Heat dissipated by Tank $=1450-850=600 \mathrm{~W}$.

Considering the temperature of oil as $45^{\circ} \mathrm{C}$, as per standards [10], the heat dissipated by the radiator is $400 \mathrm{~W} / \mathrm{m}^{2}$. Therefore, the estimated surface area is given by $(600 / 400)=1.5 \mathrm{~m}^{2}$.

\subsection{Design of Radiator}

It is a standard practice [12] to mount the radiator top pipe at a distance of $90 \mathrm{~mm}$ from the lid and $10 \mathrm{~mm}$ clearance at bottom of tank. From Fig.11, height of the radiator is given by

height of the tank - clearances - pipe diameter

$=780-100-145-10=520 \mathrm{~mm}$

Surface area $/ \mathrm{fin}=0.226 \mathrm{~m}^{2}$, no of fins is given by surface area / surface area per fin and is approximately equal to 12 fins.

\section{EFFICIENCY OF AUTOTRANSFORMER}

The efficiency of an autotransformer is given by

$\% \eta=\frac{\mathrm{kVA} * \mathrm{x}}{(\mathrm{kVA} * \mathrm{x})+\left[\left(\mathrm{x}^{2} * \text { load loss }\right)+\text { no load loss }\right]}$

Where,

$\mathrm{x}=$ fraction of load or percentage of load

\subsection{Efficiency of conventional Autotransformer}

As per IS standards 2026, the maximum permissible current density is $3.63 \mathrm{~A} / \mathrm{mm}^{2}$ and this value is considered for computing load losses for a conventional autotransformer. All the parameters defined in section 2 are estimated and summarised below:

The cross section of conductor $=2.65 \mathrm{~mm}^{2}$,

diameter of bare wire $=1.85 \mathrm{~mm}$,

length of common winding $=315 \mathrm{~mm}$,

turns per layer $=139$ turns for first two layers \&

82 turns for the last layer,

No of layers for common winding $=3$,

length of mean turn $=0.5683 \mathrm{~mm}$, length of wire $=615 \mathrm{~mm}$,

resistance per phase $@ 75^{\circ} \mathrm{C}=1.63 \Omega$,

weight of the conductor $=14.66 \mathrm{~kg}$,

stray loss of the conductor $=0.051 \%$,

specific loss $=1.02$,

build factor $=1.3$,

core losses $=390 \mathrm{~W}$,

load losses of common winding $=465 \mathrm{~W}$,

load losses of series winding losses $=512 \mathrm{~W}$,

tank losses $=110 \mathrm{~W}$,

total losses in conventional auto transformer is given by

core losses + series winding loss + common winding loss + tank loss

$=390+465+512+110=1477 \mathrm{~W}$

Total load losses is given by

Total losses-core losses $=1477-390=1087 \mathrm{~W}$

Efficiency of a conventional auto transformer $\eta_{c}$ for $50 \%$ taping at unity power factor is given by

$\% \eta_{\mathrm{c}}=\frac{110 * 0.5}{(110 * 0.5)+\left[\left(0.5^{2} * 1087\right)+390\right]}=98.80 \%$

\subsection{Efficiency of Energy efficient Autotransformer}

From section 2,

Core losses $=190 \mathrm{~W}$,

Total load losses $=975 \mathrm{~W}$

Total losses $=975+190=1165 \mathrm{~W}$

Efficiency of a energy efficient auto transformer $\eta_{\mathrm{e}}$ for $50 \%$ taping at unity power factor is given by

$\% \eta_{\mathrm{e}}=\frac{110 * 0.5}{(110 * 0.5)+\left[\left(0.5^{2} * 975\right)+190\right]}=99.21 \%$

From above total reduction in losses in energy efficient autotransformer compared to conventional autotransformer is given by

$1477-1165=312 \mathrm{~W}$

In a year total number of units saved is given by $0.312 * 24 * 365=2733 \mathrm{kWh}$

The life of the transformer is expected to be 30 years. Therefore, total number of units saved in 30 years $=2733 * 30=81993 \mathrm{kWh}$.

At present, cost of one unit $=$ Rs. 5.25

Total savings in $\mathrm{Rs}=81993 * 5.25=$ Rs. $4,30,469$

\section{CONCLUSIONS}

This paper provides a detailed analysis of a design of a $6.6 \mathrm{kV}, 110 \mathrm{kVA}$ energy efficient Autotransformer for starting a three phase induction motor of rating $6.6 \mathrm{kV}$, $250 \mathrm{~kW}$. In the present work, core losses are reduced by selecting superior material in place of conventional material i.e. laser scribed 23ZDMH85. The core losses were brought down from $390 \mathrm{~W}$ to $190 \mathrm{~W}$ by using this superior material. To reduce the load losses, lower current density conductor $3.07 \mathrm{~A} / \mathrm{mm}^{2}$ was preferred in lieu of standard value $3.68 \mathrm{~A} / \mathrm{mm}^{2}$ (IS - 2026). The total estimated losses for an energy efficient autotransformer and conventional autotransformer are $1165 \mathrm{~W}$ and $1477 \mathrm{~W}$ respectively and there is a significant reduction in losses 
of about $22 \%$ when compared to a conventional transformer.

In the present work, the total losses of the energy efficient autotransformer are $1165 \mathrm{~W}$ which are well within the permissible limits [13] and thus validates the method of estimation of total losses with IS standards. The life of the autotransformer was assumed to be about 30 years and the total net savings will be about Rs 4,30,469. The estimated efficiency of the autotransformer operating at 50\% tapping, unity power factor with energy efficient autotransformer and conventional autotransformer was $99.21 \%$ and $98.8 \%$ respectively. This detailed information helps an electrical engineer to design an energy efficient autotransformer of any rating.

\section{ACKNOWLEDGMENTS}

The work has been carried out by the support of Sara consultants, Bangalore and we are highly thankful to them. Authors are grateful to the Director, Head of Electrical \& Electronics Engineering department \& Management of School of Engineering \& Technology, Jain University, Bangalore for their constant support and encouragement, in carrying out this work.

\section{NOMENCLATURE}

$\mathrm{K}=$ Transformation ratio

$\mathrm{I}_{\mathrm{sc}}=$ Short circuit current, A

$\mathrm{D}=$ diameter of the core, $\mathrm{mm}$

ID $=$ Inner diameter of conductor, $\mathrm{mm}$

$\mathrm{OD}=$ Outer diameter of conductor, $\mathrm{mm}$

$\mathrm{A}_{\mathrm{i}}=$ Net area, $\mathrm{mm}^{2}$

$\mathrm{f}=$ Supply frequency, $\mathrm{Hz}$

$\mathrm{B}=$ Flux density, tesla

$\mathrm{HV}=$ High voltage

$\mathrm{LV}=$ Low voltage

$\mathrm{CRGO}=$ Cold rolled grain oriented

$\mathrm{L}=$ Window height, $\mathrm{mm}$

$\mathrm{A}=$ Centre to center distance, $\mathrm{mm}$

$\mathrm{H}=$ height of transformer tank, mm

$\mathrm{b}=$ Width of conductor without insulation, $\mathrm{mm}$

$b_{i}=$ Width of conductor with insulation, $\mathrm{mm}$

$\mathrm{h}=$ Radial height

$\mathrm{W}_{\mathrm{s}}=$ Stray loss,$\%$

$\mathrm{W}_{\mathrm{L}}=$ Load loss, $\mathrm{W}$

$\operatorname{lmt}=$ Length of mean turn, $\mathrm{m}$

$(\mathrm{T} / \mathrm{l})=$ Turns per layer

$\mathrm{J}=$ Current density, $\mathrm{A} / \mathrm{mm}^{2}$

$\mathrm{w}=$ Weight of bare conductor, $\mathrm{kg}$

$\mathrm{w}_{\mathrm{i}}=$ Weight of conductor with insulation, $\mathrm{kg}$

$\mathrm{HP}=$ Horse power $=735.5$ watts

$\mathrm{EMF}=$ Electromotive force

Received April 4, 2016, accepted October 20, 2016

\section{REFERENCES}

[1] RAJPUT, R. K.: Electric Machines, Lakshmi publishers, fourth edition, pp. 350.

[2] ROGERS, D. J.: An active shunt diverter for on-load tap changers, IEEE Transaction's on power delivery, Volume 28, Issue 2, April 2013, pp. 649-657.
[3] WENZHOU, TIAN - YECHAO, ZHUZEXIYUAN - ZONGHAN, LOU: Effect of laser scribing on grain oriented silicon steel, Proceedings of International conference of electronic and mechanical engineering and information technology, 2012, pp. 1304-1307.

[4] AJAY, KHATRI - RAHI, O. P.: Optimal design of Transformer: A compressive bibliographical survey, Proceedings of International journal of scientific engineering and technology, Volume 1 , Issue $2,1^{\text {st }}$ April 2012, pp. 159-167.

[5] HARSHA, VANJANI - MEGHA, KHATRI: Comparison of conventional motor starters and modern power electronic starters for induction motors, Proceedings of Indian journal of research, Volume 1, Issue 1, Jan. 2012, pp. 28-30.

[6] FARR, L. B.: Medium voltage reduced voltage autotransformer starter failures, Proceedings of IEEE Transactions on Industry applications, Volume 1, Issue 2, March-April 2005, pp. 502-506.

[7] SEWANCHOI, PRASAD - ENJETI, N. - IRA J. PITEL: Autotransformer configurations to enhance utility power quality of high power ac/dc rectifier systems, IEEE proceedings on particle Accelerator Conference, Volume 3, $1^{\text {st }}-5^{\text {th }}$ May 1995, pp. 19851987.

[8] KULKARNI, S. V. - KHAPARDE, S. A.: Transformer Engineering Design, Technology, and Diagnostics. second edition, CRC press, Taylor \& Francis group, 2013, pp. 275.

[9] GOWDA, H. N. S.: A hand book on Transformer engineering: Sara consultants, Bangalore, www.saraconsultants.com, pp. 57.

[10] INDIAN STANDARDS IS 2026 for transformers.

[11] INDRAJIT DASGUPTA: Design of Transformers, Tata McGraw-Hill Education, 2008, pp. 63-83.

[12] INDRAJIT DASGUPTA: Power transformers Quality Assurance, New Age International (P) Limited publishers, 2009, pp. 92-104.

[13] Indian standards IS 1180, outdoor type oil immersed distribution transformers upto and including 2500 $\mathrm{kVA}, 33 \mathrm{kV}$ - specification part 1 mineral oil immersed, pp. 8, 2014.

\section{BIOGRAPHIES}

Madhu Palati was born on 02.01.1980. He received the B. Tech degree in Electrical \& Electronics Engineering from Sri Venkateshwara University, Tirupati, India, in 2003. M. E from M. S. University, Baroda, India in 2005. $\mathrm{PhD}$ from Jain University, Bangalore, India in 2016. He has worked as a software Engineer in Keane India Ltd, Gurgaon for a period of one and half years and in IBM Private Limited, Bangalore for a period of three years. He is currently working as Assistant Professor in the department of Electrical \& Electronics Engineering, School of Engineering \& Technology, Jain University, Bangalore. 
Ramaswamy Tirunellai Venkatadhri was born on 10.10.1963. He has Proficiency in Electrical Insulation Measurement \& Introduction to Power Electronics from Indian Institute of Science, Bangalore and Diploma in Electrical Engineering from Institution of Engineers (India). He is a Member of Institution of Engineers (India), Worked as an Engineer at M/s NGEF Limited, Bangalore - a Government Undertaking from 1974 to 1994. Produced a Technical Hand Book for Engineers at NGEF Ltd, Served as Secretary to Engineers Association at NGEF Ltd. He has developed a Software to Nigerian Electricity Authority for the professional Engineers on Transformers, Worked on a USAID project to teach Engineers in Afghanistan to repairs of transformers and design transformers. He also assisted in setting up Design Offices at KAVIKA, Bangalore, Universal Transformers, Bangalore, Skipper Electrical - Rajasthan and Mahashakthi Energy - Punjab. Currently he is Proprietor of Sara Consultants, engaged in assisting transformer Industry for the past 20 years. He is passionate to teach transformer designs and trained fresh Graduate Engineers in designing transformers at Kirloskar Electric Co. Ltd., Mysore and Victory Electricals - Hyderabad.
Akshata Kamagouda was born on 11.06.1993. She received the Btech degree in Electrical \& Electronics from Jain University, Bangalore in 2015. Currently she is working as hardware engineer at Shirvanthe Technologies Pvt Ltd, Bangalore.

Prashanth Ilkal was born on 31.06.1993. He received the Btech degree in Electrical \& Electronics from Jain University, Bangalore in 2015. Currently he is working as Process Executive at Infosys, Bangalore.

Shilpa Lagamannanagarale was born on 08.06.1993. She received the Btech degree in Electrical \& Electronics from Jain University, Bangalore in 2015. Currently she is preparing for MBA.

Umadevi Hanumantharayappa was born on 19.11.1992. She received the Btech degree in Electrical \& Electronics from Jain University, Bangalore in 2015. Currently she is working as Engineer at Bosh Pvt. Ltd, Bangalore. 